UDC 622.245 .42

V. M. Orlovskyy ${ }^{1}$, Cand. Sc. (Tech.), orcid.org/0000-0002-8749-5354,

V.M.Savyk ${ }^{2}$, Cand. Sc. (Tech.), orcid.org/0000-0002-0706-0589,

P. O. Molchanov' ${ }^{2}$ Cand. Sc. (Tech.), orcid.org/0000-0001-5335-4281,

A. M. Pokhylko ${ }^{2}$, orcid.org/0000-0003-4565-3411
DOI: $10.29202 / \mathrm{NVNGU} / 2018-4 / 2$

1 - O. M. Beketov National University of Urban Economy in Kharkiv, Kharkiv, Ukraine, e-mail: svaroh13@ukr.net

2 - Poltava National Technical Yuri Kondratyuk University, Poltava, Ukraine, e-mail: savicppntu@rambler.ru; petja_men@ ukr.net; misyac@i.ua

\title{
SIMPLIFIED PLUGGING MATERIAL
}

Purpose. To receive plugging material of lower density based on the mixture of viscous (Portland cement PCTI100, PCTI-50) and relieving additive. To realize it, we used expanded perlite sand as relieving additive for viscous material. To prove that plugging material based on standard plugging Portland cement and expanded perlite sand has high technological properties and corresponds with current standards.

Methodology. The research was performed with the usage of theoretical and experimental methods. Experimental studies were carried out using laboratorial equipment that models the pressure and the temperature of productive layer. Measuring the technological characteristics of plugging solution and formed stone was accomplished with the usage of standard registering equipment. The density of plugging mixture was scaled with the pycnometer, water and mixture ratio of solutions was chosen with the usage of the dehiscence cone DC-1; water separation of plugging material was measured according to the standard methodology (DSTU BV.2.7-86-99 being still legal), the time of setting time of plugging solution was defined with the consistometer KS-3, for researching of adhesion there was used the laboratorial press PSU-10 with hydraulic drive and special console, defining the extreme parameters of stone tightness while bending was carried on according to DSTU BV.2.7-86-99 on special equipment for testing the line objects to stretch while bending and pressing using the press PSU-10. The number of carried out experiments is enough to obtain results with confiding probability of 0.95 .

Findings. Relieving mixture based on plugging Portland cement PCTI-100 (PCTI-50) with the relieving additive was developed and studied. The minimal density of plugging solution based on offered material is $1160-1190 \mathrm{~kg} / \mathrm{m}^{3}$ while following other characteristics of plugging solution and stone according to the legal standards.

Originality. Effective recipes of plugging solution of lower density based on standard plugging Portland cement and relieving additive - expanded perlite sand - were developed and chosen.

Practical value. Development of the recipes of plugging solutions is perspective while cementing the wells, which have been drilled for oil and gas, especially in complicated mining and geological conditions of geological-prospecting areas and exploiting the hydrocarbon deposits. "Recommendations as for the usage of easy (simplified) plugging materials for wells cementing" were formulated, which have been accepted to use in the system of the State geological service of Ukraine.

Keywords: plugging solution, relieving additive, the toughness of plugging stone, the adhesion, the gas invasion

Introduction. While cementing wells with low and anomaly low layer pressures (ALLP), with facts of absorbing of plugging solutions and geostatic temperatures to $70{ }^{\circ} \mathrm{C}$, and also when it is necessary to lift plugging solution on the height for one cycle of pumping, we need plugging materials with lower density of cement solution.

Now the industry of Ukraine extensively produces only one kind of simplifying plugging cement PCTIIIПol5-100 with low limit of solution density of $1450 \mathrm{~kg} / \mathrm{m}^{3}$, which can be used at temperatures higher than $50{ }^{\circ} \mathrm{C}$ (the works of Gorskiy V. F.). However, currently in the majority of oil and gas enterprises there are conditions, for which we need to use simplified and even easy plugging materials. That is why, there is a need to perform studies on getting simplified $(\rho) \geq 1400 \div \leq 1650 \mathrm{~kg} / \mathrm{m}^{3}$ and easy $\left(\rho \leq 1400 \mathrm{~kg} / \mathrm{m}^{3}\right)$ plugging solutions.

Analysis of the recent research and publications. Simplified plugging solutions relegate to modified materials

(C) Orlovskyy V. M., Savyk V. M., Molchanov P. O., Pokhylko A. M., 2018
[1]. There are several ways to decline the density of plugging materials and solutions [1-4].

The authors A.I. Bulatov and V.S. Danyushevskiy suggest usage of additives with low density: 1 . Those which need water (clay, flask, and others). 2. Those which do not need water (gilsonite) while chemical reactions. 3. Additives that contain air (claydite, ashes, and so forth).

Work [2] offers to reach the descent of mixture density by adding limestone and pumice stone followed by the mixture processing with sodium hypochlorite. Cement solution that implicates processed pumice stone has shown higher density compared with processed limestone. Apart from it, work results have proved the development of technological characteristics of mixture after its processing with sodium hypochlorite.

In the literature there are demonstrated results of studies of simplified plugging solutions with inserting of ceramic and glass microspheres (cenosphere). Qualitative figures of these solutions allow using them to cement sea wells. 
Authors [4] apply the following additives of low density: vermiculite, trembling, aluminosilicate hollow microspheres with the diameter from 10 to $100 \mathrm{mcm}$. Using these easy agents effectively declines suspension density from $1.83 \mathrm{~g} / \mathrm{cm}^{3}$ to $1.50-1.54 \mathrm{~g} / \mathrm{cm}^{3}$. It is recommended to use the polymer for reducing the solution viscosity while applying all mentioned easy agents. When the concentration of easy agents is higher than $10 \%$, then the dehiscence of cement solution declines.

Generalized review and analysis of literary sources show that the most frequently used are such techniques for decreasing the density of plugging solutions as:

1) the decrease in the density of hard phase with the way of inserting an easy filler or using the viscous substance with lower density;

2) the increase in water and mixture ratio with parallel increase in mixture water keeping ability;

3 ) including in the composition of plugging solution the gas phase with its synchronous dispersing and stabilization of produced foam by:

a) the aeration of plugging solutions;

b) the addition of synthetic or natural microparticles (capsules);

c) the usage of specially modified expanded materials with high degree of cavity and small bulk mass as an additive;

4) the usage of hydrocarbon liquid with lower density instead of water;

5) the combined instrumentalities.

The method to relieve plugging solution is defined by mining and geological characteristics of the layer and technical and technological resources of the enterprise that makes plugging.

The most widespread in Ukraine are simplified plugging materials, which refer to the first two ways of their receiving, and are also based on their mixed usage in plugging mixtures.

Ukrainian industry used synchronous decrease in the density and increase in water and mixture ration for preparation of simplified plugging materials.

In the 1970s in the USSR there were produced simplified plugging cements CTF and SPC. The composition of the first one consists of slag: Portland cement clinker + trembling $=1: 1$ (by mass). The composition of the second one consists of slag + clays (for instance, bentonite). At the same time, the parameters of plugging solutions based on CTF were: the density $-1450 \div$ $\div 1600 \mathrm{~kg} / \mathrm{m}^{3}$; water and mixture ration $(\mathrm{W} / \mathrm{M})=0.7 \div$ $\div 1.1$; the temperature limits of usage $-40 \div 150{ }^{\circ} \mathrm{C}$. However, the parameters of plugging solutions based on SPC were: the density $-1450 \div 1550 \mathrm{~kg} / \mathrm{m}^{3}$; water and mixture ration $(\mathrm{W} / \mathrm{M})=0.85 \div 0.95$; the temperature limits of usage for SPC-120 - 80 $\div 160{ }^{\circ} \mathrm{C}$ and for SPC$200-160 \div 220{ }^{\circ} \mathrm{C}$ (works by Novokhatskyi D. F.).

In Ukraine there have been devised simplified cements PCTIII-Pol5-100 and PCTIII-Pol4-100, whose recipe includes cement clinker: zeolite tuff $=1: 1.3 \%$ of plaster (works of Novohatskiy D. F.). The parameters of plugging solutions based on these cements are as follows: the density $-1400 \div 1500 \mathrm{~kg} / \mathrm{m}^{3}$ when $\mathrm{W} / \mathrm{M}=1$. The temperature limits of usage are $50 \div 100{ }^{\circ} \mathrm{C}$.
Along with that, the search for new highly effective, tough and cheap additives of low density is going on. The demand of the industry for their production focuses on the necessity of revealing a bigger amount of deposits in complicated mining and geological conditions.

Objectives of the article. It implies the production of simplified (easy) plugging solution for cementing of oil and gas wells with difficult mining and geological characteristics and research of its technological parameters.

Presentation of the main research and explanation of scientific results. Researchers of Poltava Department of Ukrainian State Geological Prospecting Institute obtained simplified (easy) plugging solution with qualitative technological parameters based on existing plugging cements PCTI- 100 (from 88 to $95 \%$ ), (PCTI-50) (from 88 to $97 \%$ ) [5] and additives - expanded perlite sand (EPS)[6].

Expanded perlite sand is received by the way of thermal action on volcanic rock of perlite at the temperature of $800 \div 1000{ }^{\circ} \mathrm{C}$. While heating the components of perlite of shell-kind structure are expanded and there is steamed $3 \div 5 \%$ of linked water and the volume of material increases by $10-20$ times.

According to the oxides, expanded perlite sand (EPS) has the following composition: $65 \div 75 \% \mathrm{SiO}_{2}$ and $10 \div 15 \% \mathrm{Al}_{2} \mathrm{O}_{3}$ and contains $\mathrm{Fe}_{2} \mathrm{O}_{3}, \mathrm{CaO}, \mathrm{MgO}$, $\mathrm{Na}_{2} \mathrm{O}, \mathrm{K}_{2} \mathrm{O}$.

Depending on fractional composition there are two modifications of expanded perlite sand (EPS): row (EPS(R)) and small dispersed (EPS(D)). Together with it, there is also division into categories in each of mentioned types according to bulk masses of $1 \mathrm{~m}^{3}$ of material. Row expanded perlite sand $(\operatorname{EPS}(\mathrm{R}))$ is produced in three labels: $75,100,150$, and small dispersed expanded perlite sand is devised in three labels: 75, 100 . The label of expanded perlite sand corresponds with the mass of $1 \mathrm{~m}^{3}$ of material in kilograms.

Particular shell-type structure of grains of relieving additive (its porosity is $80 \div 90 \%$ ) causes filling plugging material with air in the process of mixing.

The mass fraction of perlite sand EPS in the studies is as follows: $\operatorname{EPS}(\mathrm{R})-100-3-12 \%$; $\operatorname{EPS}(\mathrm{R})-75-5-$ $7.5 \%$; EPS(M)-100-5-10\%.

The water and mixture ratio (W/M) in the studies was $0.65-0.98$.

The additive NTPhA, $\%$ from the mass of dry material is 0.01 .

There were explored technological properties of simplified (easy) plugging solutions with additives of EPS [7].

The analysis of research results testifies:

- the easiest plugging solution with the density of $1160 \mathrm{~kg} / \mathrm{m}^{3}$ was obtained based on the mixture of Portland cement PCTI-100 (the part in the mixture was $88 \%$ ) and expanded perlite sand EPS(R)-100 (the part in the mixture was $12 \%), \mathrm{W} / \mathrm{M}=0.95$, and the additive NTPhA was absent [8];

- the hardest plugging solution with the density of $1510 \mathrm{~kg} / \mathrm{m}^{3}$ has been got based on the mixture of Portland cement PCTI-50 (the part in the mixture was $97 \%$ ) and expanded perlite sand EPS(R)-100 (the part 
in the mixture was $3 \%$ ), $\mathrm{W} / \mathrm{M}=0.65$, and the additive NTPhA was absent;

- with fixed content of expanded perlite sand (EPS) in the way of water and mixture ratio $(\mathrm{W} / \mathrm{M})$ varying it is possible to regulate the density of plugging solution within from 2 to $8 \%$ and save appropriate technological solution parameters;

- simplified and easy plugging solutions with the additives of expanded perlite sand (EPS) are sedimentation stable according to the requirements of the State standard;

- the pumping of plugging solution with the density of $1240-1400 \mathrm{~kg} / \mathrm{m}^{3}$ while $t=50^{\circ} \mathrm{C}, P=20 \mathrm{MPa}$ is within from $1 \mathrm{~h}$. $55 \mathrm{~min}$. to $3 \mathrm{~h}$; while $t=70^{\circ} \mathrm{C}, P=30 \mathrm{MPa}$ it is for $3 \mathrm{~h}$.; the additive to the composition of plugging material of relieving additive decreases the term of plugging solution pumping; simultaneously, the setting time of such solutions is adjusted by standard retarders, such as NTPhA;

- the dehiscence of probed solutions is within 0.190$0.220 \mathrm{~m}$. Along with that, when the minimal density is $1160 \mathrm{~kg} / \mathrm{m}^{3}$, it is $0.200 \mathrm{~m}$, and, on the contrary, with the maximum density of $1510 \mathrm{~kg} / \mathrm{m}^{3}$ it is $0.220 \mathrm{~m}$;

- the water separation of simplified and easy plugging solutions changes from 0 to $10 \mathrm{~cm}^{3}$. For the density of $1160 \mathrm{~kg} / \mathrm{m}^{3}$ it is $0 \mathrm{~cm}^{3}$, and for $1510 \mathrm{~kg} / \mathrm{m}^{3}$ it reflects as $1.5 \mathrm{~cm}^{3}$.

Rheological parameters are one of the main characteristics of plugging material, on whose degree hydraulic supports in the process of plugging works and the quality of pushing of watering liquid by plugging solution depend.

The studies of rheological solution parameters based on new simplified plugging material were carried out on the rotary viscometer Reotest-2. There was taken the value of spring spin re-created in the arrow bending on the scale of the indicatory appliance $a$ while different speeds of rotations in the internal cylinder (and, relevantly, diverse moments). Having multiplied by corresponding coefficient $K$, which is proportional to the diameter of the internal cylinder, we found the tangential tension of slide

$$
\tau=K a,
$$

where $\tau$ is the tangential tension of slide; $K$ is the coefficient that is up to the diameter of the internal cylinder; $a$ is the arrow bending on the scale of the indicatory appliance.

On the results, there were made charts of functions dependences between tangential tension of slide $\tau$ from the gradient of speed deformation in the slide $\gamma: \tau=f(\gamma)$ within $\gamma$ from 1.0 to $434.4 \mathrm{~s}^{-1}$.

Concentrated cement dispersions, except viscously plastic ones, have thixotropic properties; it means they are able to recover structural and mechanic characteristics after disruption. Instead of certain structural links in the process of hydration they draw up others. It really complicates the research of structural and mechanic (rheological) parameters of cement dispersions. For full characteristics of such unstable systems, besides dynamic tension of slide and plastic viscosity, it is needed to consider extra parameters. To describe the model of solutions flow based on simplified plugging material the most applicable is the equation of Gershel-Balkli [9]

$$
\tau-\theta_{0}=M \gamma^{n}
$$

where $\tau$ is the tangential tension of slide; $\theta_{0}$ is the maximum tension of slide; $M$ is the plastic viscosity $\eta_{p l}$ according to Keson; $\gamma$ is the gradient of speed deformation in the slide; $n$ is the flow index.

While $\theta_{0}=0$ the equation (2) transforms into the power equation of Osvald de Vaale

$$
\tau=M \gamma^{n} \text {. }
$$

Considering the fact that with high gradient figures of slide deformation speed $\left(\gamma>150 \mathrm{c}^{-1}\right)$ the fields of rheological curved flows of simplified plugging solutions are close to the rectilinear $(n=1)$, the equations (2) and (3) are transformed with such simplifications in the equation of Shvedov-Bingam

or

$$
\tau-\tau_{0}=M \gamma
$$

$$
\tau-\tau_{0}=\eta_{p l} \gamma .
$$

Having prolonged the rectilinear field of rheological curved lines to the cross with the axis " $\tau$ " and using the equation (5) we define the dynamic tension of slide.

The value $\tau_{0}$ corresponds with the tension, during which the structure of plugging solution begins disrupting with stable speed. And the pace of such disruption is determined by the formula $\eta_{p l}=\frac{\tau-\tau_{0}}{\gamma}$.

In Table 1 there are results of calculating $\eta_{p l}$ and $\tau$. Having analyzed them in details, we make the following conclusions: with the content of EPS(R) increasing, the viscosity of cement dispersion decreases as a result of increase in water and mixture ration $\mathrm{W} / \mathrm{M}$ and the dynamic tension of slide changes insignificantly, apart from the mixture, in which the concentration of additives is $10 \%$ that testifies a crucial degree of the system structure. The cement dispersion with the additives EPS(D) behaves in the same way.

While heating the solution from 20 to $50{ }^{\circ} \mathrm{C}$ there is small decrease in $\eta_{p l}$ and increase in $\tau_{0}$.

For analysis of flow of plugging dispersions bigger explanation about system state is given not by plastic viscosity, but effective viscosity $\eta_{e f}$, which characterizes the balance between disruption and recovering of connections.

Figure $a$ there shows the dependence of $\eta_{e f}$ on $\tau$ in logarithmic coordinates $\lg \eta_{e f}=f(\tau)$.

The field of a curved (plugging solution based on PCTI-100) in the field of small $\tau$ is closer to a horizontal one and corresponds with Newton's viscosity of practically non-destroyed structure. In simplified solutions there are not such fields.

In the next $\eta_{e f}$ decreases, together with it, absolute value of $\eta_{e f}$ declines with increase in EPS content and water and mixture ratio. The values of the tangential tension of slide $\tau$, obtained experimentally, make it impossible to fix the second "theoretical" one closer to the horizontal field with minimal Newton's viscosity of fully non-destroyed structure.

In Figure $b$ there are dependences of $\eta_{e f}=f(\gamma)$ in logarithmic scales. The change in effective viscosity of 
solution $\eta_{e f}$ from $\gamma$ (the speed of deformation) approaches the straight line. The angle of its bending is defined by the pace of structure disruption; it is minimal for dispersion based on PCTI-100.

For calculation of pressures while cementing of strapping columns, parameters $\eta_{p l}$ and $\tau$, are used; they are shown in Table 1.

Comparative calculations of pressures in the end of pushing with the usage of simplified plugging solutions and solutions based on standard simplified cement while cementing the first sections of 324 and $245 \mathrm{~mm}$ of columns, are shown in Table 2.

The data of Table 2 testifies that using of new simplified plugging material (SPM) evokes the pressures in the end of pushing being lower than absorbing pressures but while using the standard plugging cement PCIIIPol5-100 they are higher. It indicates necessity to use new simplified plugging solutions for the layers with low pressures of absorbing.

Hydraulic calculation were made in the mathematical editor MathCad using the legal document "Hydraulic calculations while cementing wells", developed at PD USGPI.
In the process of conducting scientific and research works there were studied such physical and mechanical properties of stone from simplified (easy) plugging solutions as: toughness, adhesion to metal, and gas invasion $[7,8]$.

In experiments the following composition of outcome plugging mixture was taken:

- plugging cement of labels PCTI-100 or PCTI-50 the mass fraction is $88,90,92,93,95,97 \%$;

- expanded perlite sand EPS(R) - the mass fraction is $3,5,7,10,12 \%$ or $\operatorname{EPS}(\mathrm{D})-5,8,12 \%$.

The temperature regime can be as follows: when it is used the cement PCTI-100: 60, $80{ }^{\circ} \mathrm{C}$; while using PCTI-50: $20,40{ }^{\circ} \mathrm{C}$.

The minimal density of solutions based on mentioned mixtures was $1190 \mathrm{~kg} / \mathrm{m}^{3}$ (it corresponds with the mixture composition of PCTI-100(50) - $88 \%$, EPS(R) - $12 \%)$. The maximum density of simplified solution was $1550 \mathrm{~kg} / \mathrm{m}^{3}$ (the mixture composition includes PCTI-100(50) - $97 \%$, EPS(R) - $3 \%)$.

The toughness of the obtained plugging stone was defined during the tests on bending and pressing at the temperatures of $20,40,60,80^{\circ} \mathrm{C}$.

Table 1

Rheological parameters of easy (simplified) plugging solutions

\begin{tabular}{|c|c|c|c|c|c|c|c|c|c|}
\hline \multirow{2}{*}{ № } & \multicolumn{4}{|c|}{ The composition, $\%$} & \multirow{2}{*}{$\mathrm{W} / \mathrm{M}$} & \multicolumn{2}{|c|}{$t=20^{\circ} \mathrm{C}$} & \multicolumn{2}{|c|}{$t=50^{\circ} \mathrm{C}$} \\
\hline & PCT -100 & PCT-50 & EPS(R) & EPS(D) & & $\eta, \mathrm{Pa}$ s & $\tau, \mathrm{N} / \mathrm{m}^{2}$ & $\eta, \mathrm{Pa}$ 's & $\tau, \mathrm{N} / \mathrm{m}^{2}$ \\
\hline 1 & 100 & - & - & - & 0.5 & 0.046 & 12.0 & 0.038 & 15.2 \\
\hline 2 & - & 100 & - & - & 0.55 & 0.056 & 17.4 & - & - \\
\hline 3 & - & 95 & 5 & - & 0.73 & 0.052 & 18.3 & - & - \\
\hline 4 & - & 93 & 7 & - & 0.80 & 0.041 & 15.1 & - & - \\
\hline 5 & - & 90 & 10 & - & 0.92 & 0.026 & 36.5 & - & - \\
\hline 6 & 95 & - & 5 & - & 0.73 & 0.022 & 5.9 & 0.021 & 7.7 \\
\hline 7 & 93 & - & 7 & - & 0.80 & 0.017 & 11.95 & 0.010 & 12.14 \\
\hline 8 & 90 & - & 10 & - & 0.92 & 0.011 & 10.1 & 0.010 & 13.8 \\
\hline 9 & 95 & - & - & 5 & 0.73 & 0.029 & 9.5 & 0.026 & 9.9 \\
\hline 10 & 92 & - & - & 8 & 0.78 & 0.022 & 7.0 & - & - \\
\hline 11 & 88 & - & - & 12 & 0.92 & 0.013 & 6.6 & - & - \\
\hline
\end{tabular}

Table 2

Calculation results of pressures on the output from the well in the end of pushing

\begin{tabular}{|c|c|c|c|c|c|}
\hline $\begin{array}{c}\text { The column } \\
\text { diameter, } \\
\text { section }\end{array}$ & $\begin{array}{c}\text { Cementing } \\
\text { interval, } \mathrm{m}\end{array}$ & $\begin{array}{c}\text { The productivity } \\
\text { while pushing, } \\
\mathrm{m}^{3} / \mathrm{s}\end{array}$ & $\begin{array}{c}\text { Used plugging } \\
\text { material, the density }\end{array}$ & $\begin{array}{c}\text { The pressure } \\
\text { on the output in the end } \\
\text { of pushing, MPa }\end{array}$ & $\begin{array}{c}\text { The pressure } \\
\text { of absorbing } \\
\text { on the output, MPa }\end{array}$ \\
\hline $\begin{array}{c}324 \mathrm{~mm}, \\
\text { I }\end{array}$ & $2600-1400$ & 0.031 & $\begin{array}{c}\text { PCTII-Pol-100, } \\
1500 \mathrm{~kg} / \mathrm{m}^{3}\end{array}$ & 35.1 & 34.1 \\
\cline { 3 - 6 } & & $\begin{array}{c}\mathrm{SPM} \\
1330 \mathrm{~kg} / \mathrm{m}^{3}\end{array}$ & 33.3 & - \\
\hline $\begin{array}{c}245 \mathrm{~mm}, \\
\text { I }\end{array}$ & $4550-2200$ & 0.025 & $\begin{array}{c}\text { PCTII-Pol-100, } \\
1500 \mathrm{~kg} / \mathrm{m}^{3}\end{array}$ & 64.2 & 62.8 \\
\cline { 3 - 6 } & & $\begin{array}{c}\mathrm{SPM}, \\
1330 \mathrm{~kg} / \mathrm{m}^{3}\end{array}$ & 59.9 & - \\
\hline
\end{tabular}



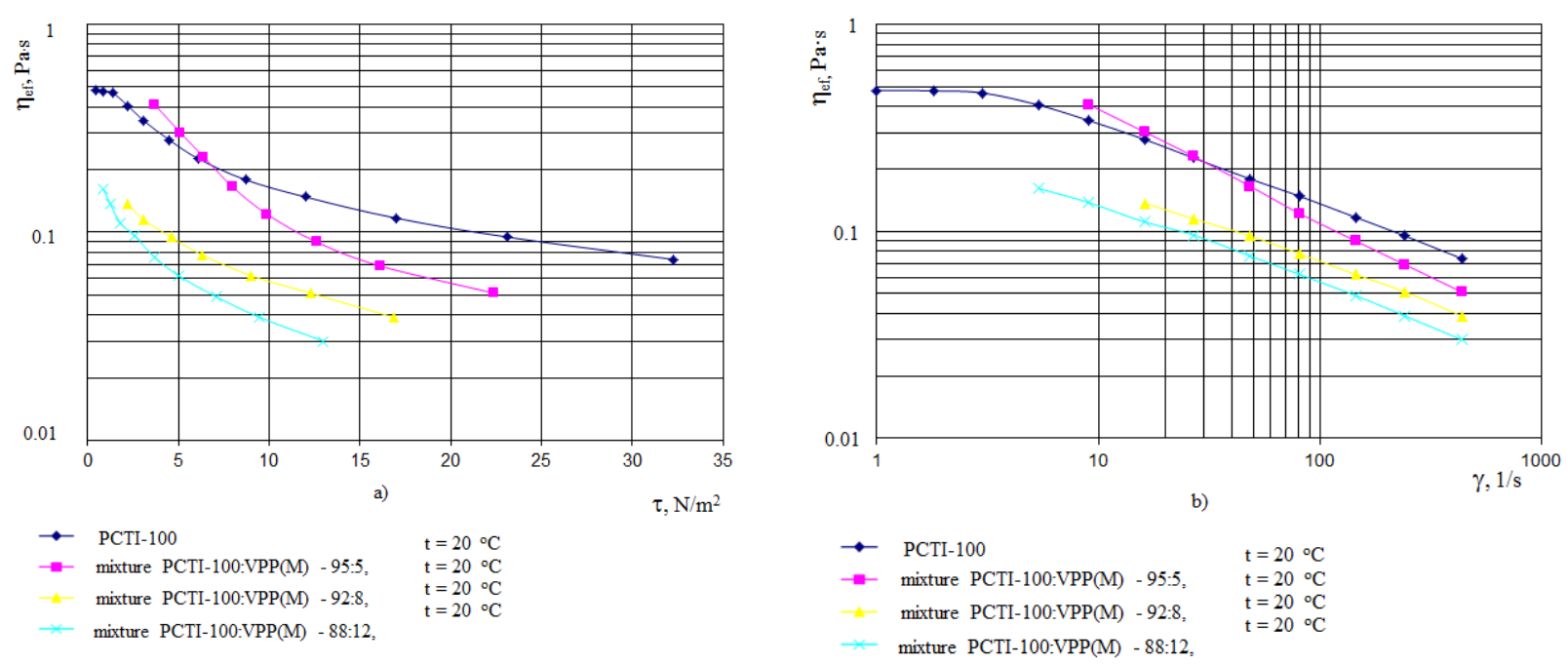

Fig. The dependences of effective viscosity $\eta_{e \phi}$ of plugging solution:

$a$-on the slide tension $\tau ; b$-on the slide deformation $\gamma$

The gas invasion of plugging stone was defined at the temperatures of $20,40,60{ }^{\circ} \mathrm{C}$.

The adhesion of plugging stone to metal was defined at the temperatures of $20,60{ }^{\circ} \mathrm{C}$.

In laboratorial studies we obtained the following results:

- the toughness on pressing of plugging stone based on the mixture with the maximum density of $1550 \mathrm{~kg} / \mathrm{m}^{3}$ in two days of setting varies within $2.7 \mathrm{MPa}\left(t=20^{\circ} \mathrm{C}\right)-$ $7 \mathrm{MPa}\left(t=60{ }^{\circ} \mathrm{C}\right)$; the toughness in 28 days of setting is within $3.3 \mathrm{MPa}\left(t=80^{\circ} \mathrm{C}\right)-8.5 \mathrm{MPa}\left(t=80^{\circ} \mathrm{C}\right)$;

- the toughness on pressing of plugging stone based on the mixture with the minimal density of $1190 \mathrm{~kg} / \mathrm{m}^{3}$ in two days of setting varies within $0.7 \mathrm{MPa}\left(t=20^{\circ} \mathrm{C}\right)-$ $1.8 \mathrm{MPa}\left(t=60{ }^{\circ} \mathrm{C}\right)$; the toughness in 28 days of setting is within $1.5 \mathrm{MPa}\left(t=80^{\circ} \mathrm{C}\right)-3.0 \mathrm{MPa}\left(t=60{ }^{\circ} \mathrm{C}\right)$;

- the maximum toughness of plugging stone on bending in two days that was $2.4 \mathrm{MPa}$ was received for the sample from plugging solution with the density of $1450 \mathrm{~kg} / \mathrm{m}^{3}$ and the temperature of $60{ }^{\circ} \mathrm{C}$; on pressing $7 \mathrm{MPa}$ was obtained for the sample from plugging solution with the density of $1550 \mathrm{~kg} / \mathrm{m}^{3}$ and the temperature of $60{ }^{\circ} \mathrm{C}$;

- the minimal toughness on bending in two days $0.4 \mathrm{MPa}$ - was obtained for the sample from plugging solution with the density of $1200 \mathrm{~kg} / \mathrm{m}^{3}$, on pressing $0.7 \mathrm{MPa}$ (the solution with the density of $1190 \mathrm{~kg} / \mathrm{m}^{3}$, the research temperature was $60{ }^{\circ} \mathrm{C}$ );

- the gas invasion of stone is within $1.5 \mathrm{mD}\left(t=60^{\circ} \mathrm{C}\right.$, with the solution density of $\left.1400 \mathrm{~kg} / \mathrm{m}^{3}\right)-14.6 \mathrm{mD}(t=$ $=20{ }^{\circ} \mathrm{C}$, with the solution density of $1200 \mathrm{~kg} / \mathrm{m}^{3}$ );

- the adhesion to metal was derived within $0.3 \mathrm{MPa}$ $\left(t=20{ }^{\circ} \mathrm{C}\right.$, with the solution density of $\left.1200 \mathrm{~kg} / \mathrm{m}^{3}\right)-$ $2.5 \mathrm{MPa}\left(t=60{ }^{\circ} \mathrm{C}\right.$, with the solution density of $\left.1400 \mathrm{~kg} / \mathrm{m}^{3}\right)$.

We can observe the following regularities from the analysis:

- the usage of different types of EPS (EPS(R) and EPS(D)) does not influence largely the value of physical and mechanic characteristics;
- higher concentration of EPS in solution causes the decrease in toughness and adhesion values and the increase in the gas invasion. It, mainly, is evoked by the increase in water and mixture ration (W/M) in recipes of simplified plugging solutions;

- in the interval of temperatures from 20 to $60{ }^{\circ} \mathrm{C}$ the improvement of physical and mechanic characteristics of stone is observed;

- while heating to $80^{\circ} \mathrm{C}$, the toughness decreases that testifies to limited thermo resilience of simplified plugging solutions with additives of EPS;

- the stone based on simplified plugging solution corresponds with the requirements of DSTU BV.2.788-99 (legal now) regarding the toughness of simplified plugging cements.

Conclusions. Simplified (easy) plugging solutions with the density of $1160-1550 \mathrm{~kg} / \mathrm{m}^{3}$ have been obtained based on plugging Portland cement PCTI-100 (PCTI50) and relieving additive EPS with the correlation of components of viscous material with the mass from $97: 3$ to $88: 12$.

The correspondence with the standard of received simplified (easy) plugging solutions has been proved.

The temperature interval of using simplified (easy) plugging solutions has been established; its frontiers are $20 \div 60{ }^{\circ} \mathrm{C}$, while accepted ones are $15 \div 70{ }^{\circ} \mathrm{C}$.

The scientific value of the invention is the result of choice of optimal recipes to produce simplified plugging solutions with additives of EPS.

The recipes obtained give a possibility to increase the diapason of the density in simplified (easy) plugging solutions, which is required by the technology of cementing highly invasive layers and wells cuts in zones of anomaly low layer pressures and with the necessity to raise cement through height for one procedure.

Based on the data of studies in PD USGPI with the assistance of the authors "Recommendations as for the usage of easy (simplified) plugging materials for wells cementing" has been published which is accepted to use in the system of State Geological Service of Ukraine. 
In the following studies it is reasonable to consider conditions explored in the work [10] of reaching the highest efficiency of foamgenerating devices that is essentially, especially, for preparing plugging solutions while cementing layers with anomaly low layer pressures.

In further studies it is advisable to take into account the complex layered structure of water on mineral surfaces found in [11], which is important, in particular, for the effect of adhesion "tampon solution - rock".

Acknowledgement. The authors thank the workers of Poltava Department of Ukrainian State Geological Prospecting Institute (USGPI) for the study.

\section{References.}

1. Agzamov, F.A., Izmukhambetov, B. S. and Tokunova, E. A., 2011. Drilling mud and cement chemistry. Moscow: Nedra.

2. Hesham Alsharie, Talal Masoud, Aziz Ibrahim Abdulla and Aseel Ghanemt, 2015. Properties of Lightweight Cement Mortar Containing Treated Pumice and Limestone. Journal of Engineering and Applied Sciences, 10(5), pp. 96-101. DOI: 10.3923/jeasci.2015.96.101.

3. Balthar, V.K.C.B.L.M., Toledo Filho, R. D., E. de MoraesRego Fairbairn and C. R. de Miranda, 2016. Durability of Lightweight Slurries for Oilwell Cementing. Key Engineering Materials. Switzerland. - Trans Tech Publications [online], 711, pp. 203-210. Available at: $<$ https://www.scientific.net/KEM.711.203> [Accessed 9 August 2017].

4. Bubnov, A.S., Khorev, V.S. and Boyko, I.A., 2015. The effect of lightweight agents on the density of cement slurry applied during oil and gas well drilling. Scientific and Technical Challenges in the Well Drilling Progress IOP Publishing IOP Conf. Series: Earth and Environmental Science, 24(2015)012008. DOI:10.1088/1755-1315/ 24/1/012008.

5. Concern Cement, 1999. Oil-well Portland cement DSTU BV.2.7-88-99. 1999/Derzhstandart Ukrainy/ Kiev (now active) [pdf]. Available at: <http://ksv.do. am/GOST/DSTY_ALL/DSYU1/dstu_b_v.2.7-88-99. pdf $>$ [Accessed 14 August 2017].

6. GOST 10832-91. Sand and road metal perlite expanded [Effective since 1 January 1992]. / Specifications (now active) [online]. Available at: <http://www.vost. ru/docs/gost/10832-91http://ksv.do.am/GOST/ DSTY_ALL/DSYU1/dstu_b_v.2.7-88-99.pdf> [Accessed 22 September 2017].

7. Orlovskyi, V. M., Pokhylko, A. M. and Krytskyi, V. V., 2016. New lightweight plugging materials. Zbirnyk naukovykh prats UkrDHRI, 4, pp. 107-114.

8. Orlovskyi, V. M., Mykhailenko, S. H. and Luzhanytsia, O.V, 2012. The lightweight plugging materials. Ukraine. Pat. 73377. No. u 2012 01875; Declared on February 20, 12; Opubl. 25.09.12, Bul. No. 18.

9. Borzenko, E. Y. and Khehai, E. Y., 2016. The computational simulation of Balkli-Gershelya liquid stationary flow on the sharp growing supply tube. Vestnik Tomskogo Gosudarstvennogo Universiteta. Matematika i Mehanika, 1(39), pp 68-81. DOI: 10.17223/19988621/ $39 / 8$.
10. Lyakh, M. M., Savyk, V. M. and Molchanov, P. O., 2017. Experimental and industrial research pinogenerating devices. Rozrobka korysnyh kopalyn. Naukovyi Visnyk Natsionalnoho Hirnychoho Universytetu, 5(161), pp. 17-23.

11. Biletskyi, V.S., Shendrik, T. and Sergeev, P., 2012. Derivatography as the method of water structure studying on solid mineral surface. In: Geomechanical Processes During Underground Mining. London: CRC Press Taylor \& Francis Group [online], pp. 181-184. Available at: <http://www.crcnetbase.com/doi/abs/10.1201/ b13157-31 $>$ [Accessed 12 October 2017].

\section{Полегшений тампонажний матеріал}

$$
\begin{gathered}
\text { В.М. Орловський }{ }^{1} \text { В.М. Савик }{ }^{2}, \text { П.О. Молчанов }{ }^{2} \text {, } \\
\text { А. М. Похилко }
\end{gathered}
$$

1 - Харківський національний університет міського господарства імені О.М.Бекетова, м. Харків, Україна, e-mail: svaroh13@ukr.net

2 - Полтавський національний технічний університет імені Юрія Кондратюка, м. Полтава, Україна, е-mail: savicppntu@rambler.ru; petja_men@ukr.net; misyac@i.ua

Мета. Отримання тампонажного матеріалу зниженої густини на основі суміші в'яжучого (портландцемент ПЦТІ-100, ПЦТІ-50) і полегшувальної домішки. Для реалізації цієї мети як полегшувальну домішку до в'яжучого матеріалу застосовано спучений перлітовий пісок. Довести, що отриманий тампонажний матеріал на основі стандартного тампонажного портландцементу та спученого перлітового піску має високі технологічні властивості й відповідає діючим стандартам.

Методика. Дослідження проведене із застосуванням теоретичних і експериментальних методів. Експериментальні дослідження проведені на лабораторному обладнанні, що моделює тиск і температуру продуктивного пласта. Вимірювання технологічних характеристик тампонажного розчину та сформованого каменю проводилось із застосуванням стандартного реєструючого обладнання. Густина тампонажної суміші вимірювалася пікнометром, водосумішеве відношення розчинів підбиралось із застосуванням конусу розтічності КР-1, водовідділення тампонажного розчину вимірювалося за стандартною методикою згідно з ДСТУ БВ.2.786-99 (нині діючий), час тужавіння тампонажного розчину визначався на консистометрі КЦ-3, для дослідження адгезії застосовувався лабораторний прес ПСУ-10 з гідравлічним приводом і спеціальна приставка, визначення граничних параметрів міцності каменю при вигині проводилося згідно 3 ДСТУ БВ.2.7-86-99 на спеціальному приладі для випробовування лінійних об'єктів на розтяг при вигині, при стискуванні - на пресі ПСУ-10. Кількість здійснених експериментів є достатньою для отримання результатів 3 довірчою вірогідністю 0,95 .

Результати. Одержана й досліджена полегшена суміш на основі стандартного тампонажного порт- 
ландцементу ПЦТІ-100 (ПЦТІ-50) з полегшувальною домішкою. Мінімальна густина тампонажного розчину на основі запропонованого матеріалу складає 1160-1190 кг/м³ при дотриманні інших характеристик тампонажного розчину й каменю згідно $з$ діючими стандартами.

Наукова новизна. Одержані оптимальні рецептури тампонажного розчину зниженої густини на основі стандартного тампонажного портландцементу та полегшувальної домішки - спученого перлітового піску.

Практична значимість. Одержані рецептури тампонажних розчинів $є$ перспективними при цементуванні свердловин у складних гірничо-геологічних умовах геологорозвідувальних площ і експлуатаційних родовищ вуглеводнів України. На основі даної розробки видані „Рекомендації з використання легких (полегшених) тампонажних матеріалів для цементування свердловин“, прийняті до застосування в системі Державної геологічної служби України.

Ключові слова: полегшувальний тампонажний матеріал, полегшульвана домішка, міцність каменю, адгезія, газопроникність

\section{Облегченный тампонажный материал}

\section{В. Н. Орловський ${ }^{1}$ В. Н. Савик², П.А. Молчанов ${ }^{2}$, А. Н. Похилко}

1 - Харьковский национальный университет городского хозяйства имени А.Н.Бекетова, г. Харьков, Украина, e-mail: svaroh13@ukr.net

2 - Полтавский национальный технический университет имени Юрия Кондратюка, г. Полтава, Украина, e-mail: savicppntu@rambler.ru; petja_men@ukr.net; misyac@i.ua

Цель. Получение облегченного тампонажного материала на основе смеси вяжущего (портландцемент ПЦТІ-100, ПЦТІ-50) и облегчающей примеси. Для достижения этой цели в качестве облегчающей примеси к вяжущему материалу использован вспученный перлитовый песок. Доказать, что полученный облегченный тампонажный материал на основе стандартного тампонажного портландцемента и вспученного перлитового песка имеет высокие технологические свойства и отвечает требованиям действующих стандартов относительно облегченных тампонажных цементов.

Методика. При проведении исследований использованы теоретические и экспериментальные методы. Эксперименты проведены на лабораторном оборудовании, которое моделирует пластовые условия. Измерения технологических свойств тампонажного раствора и образованного камня проводились с использованием стандартной регистрирующей аппаратуры. Плотность тампонажных растворов определялась с помощью пикнометра, водосмесевое отношение растворов подбиралось с помощью конуса растекаемости КР-1, водоотделение тампонажных растворов определялось по стандартной методике согласно ДСТУ БВ.2.7-86-99, время загустевания тампонажных растворов определялось на консистометре КЦ-3, для изучение адгезии использовался лабораторный пресс ПСУ-10 с гидравлическим приводом и специальная приставка, определение пределов прочности камня при изгибе проводилось согласно ДСТУ БВ.2.7-8699 на приборе для испытания образцов-балочек на растяжение при изгибе, при сжатии - на прессе ПСУ-10. Количество проведенных экспериментов достаточно для получения результатов с доверительной вероятностью 0,95.

Результаты. Разработан и исследован облегченный тампонажный материал на основе стандартного тампонажного портландцемента ПЦТІ-100 (ПЦТІ-50) с облегчающей примесью. Минимальная плотность облегченных (легких) тампонажных растворов на основе разработанного материала составляет 1160-1190 кг/м³ при соблюдении других свойств тампонажного раствора и камня в соответствии с требованиями действующих стандартов.

Научная новизна. Проведена разработка и подбор оптимальных рецептур нового облегченного тампонажного материала на основе стандартного тампонажного портландцемента и облегчающей примеси - вспученного перлитового песка.

Практическая значимость. Результаты работы имеют практическое применение при цементировании глубоких скважин в сложных горно-геологических условиях геологоразведочных площадей и промышленных месторождений углеводородного сырья Украины. На основе данной разработки изданы „Рекомендации по использованию легких (облегченных) тампонажных материалов для цементирования скважин“, принятые к применению в системе Государственной геологической службы Украины.

Ключевые слова: облегченный тампонажный материал, облегчающая примесь, прочность камня, адгезия, газопроницаемость

Рекомендовано до публікації докт. техн. наук В. С. Білецьким. Дата надходження рукопису 12.04.17. 